\title{
USING A MICROSIMULATION TRAFFIC MODEL TO COMPARE TWO-LANE AND TURBO-ROUNDABOUTS
}

\author{
Ivan Kolak \\ Josip Juraj Strossmayer University of Osijek, Faculty of Civil Engineering Osijek, mag.ing.aedif. \\ Irena Ištoka Otković \\ Josip Juraj Strossmayer University of Osijek, Faculty of Civil Engineering Osijek, Assistant Professor \\ Corresponding author: iirena@gfos.hr \\ Ivana Barišić \\ Josip Juraj Strossmayer University of Osijek, Faculty of Civil Engineering Osijek, Assistant Professor
}

\begin{abstract}
Microsimulation traffic models are used to analyze and predict the functionality and safety of traffic networks, especially in critical areas such as intersections. These models have proven particularly useful in analyzing and comparing solutions in the early stages of design. In this paper, we compare the functional characteristics of an existing two-lane roundabout and a proposed replacement turbo roundabout. Our microsimulation modeling used the VISSIM traffic model, and we designed the conceptual turbo roundabout with AutoCAD and TORUS5 Roundabouts software.
\end{abstract}

Keywords: Two-lane roundabout, turbo roundabout, conceptual design, microsimulation

\section{USPOREDBA DVOTRAČNOG KRUŽNOG I TURBO RASKRIŽJA PRIMJENOM MIKROSIMULACIJSKOG PROMETNOG MODELA}

Sažetak: Mikrosimulacijski prometni modeli koriste se u analizi postojećih i predikciji budućih funkcionalnih i sigurnosnih karakteristika dijelova prometne mreže, osobito kritičnih dijelova poput raskrižja. Njihova primjena pokazala se osobito korisnom u analizi i ocjeni varijantnih rješenja u ranim projektnim fazama. U okviru ovoga rada pokazni su rezultati analize i usporedbe postojećeg dvotračnog kružnog raskrižja primarne funkcionalne razine i potencijalne rekonstrukcije u turbo kružno raskrižje. Za mikrosimulacijsko modeliranje korišten je mikrosimulacijski prometni model VISSIM, a idejno rješenje turbo raskrižja napravljeno je primjenom programa AutoCAD i TORUS 5 Roundabouts.

Ključne riječi: dvotračno kružno raskrižje, turbo raskrižje, idejno rješenje, mikrosimulacije 


\section{INTRODUCTION}

Roundabouts have been widely constructed in the last few decades, but as with any traffic solution, they have advantages and disadvantages. To evaluate the functional, security, physical, and economic conditions in constructing and maintaining roundabouts, extensive experience in applying various roundabouts is essential [1, 2]. Beyond single-lane roundabouts, two-lane and especially multi-lane roundabouts are more complex solutions because they influence the interweaving (lane changing) of traffic in the circulatory lane, which significantly affects their functionality and particularly their safety. To prevent the problem of interweaving in the inner lane, various other types of roundabouts have been developed [3,4]. One solution is the turbo roundabout, which manages traffic flows separately: prior to entering the roundabout, in the roundabout, and at the exit. It physically separates lanes with special elements (e.g., raised curbs or delineators) that prevent interweaving in the circulatory lane, only removing these barriers in specific places to allow entry into the inner lane.

The city of Osijek, Croatia, contains a classic two-lane roundabout. Because of the high traffic load and time losses at the peak hour - objective indicators of traffic safety and the users' perceptions of traffic insecurity [5] - here we explore the idea of replacing this two-lane roundabout with a turbo roundabout. We analyze and compare the alternative solutions, the basic steps in the conceptual design of the turbo roundabout, and simulate the current and designed solutions.

In the existing roundabout, the external lane is overloaded because of improper driving behavior and unbalanced use of lanes, increasing time losses and reducing safety. The turbo roundabout increases safety, and because of traffic channeling it is necessary to use the inner lane for a certain exit.

\section{CURRENT ROUNDABOUT}

The first and largest roundabout in Osijek is the Đakovština roundabout, near the city center, designed in 1995. It is located at the intersection of Vinkovačka, Reisnerova, Županijska, and Sv. Leopolda B. Mandića streets. This two-lane, elliptical roundabout has five approaches, three of which are single-lane and two are two-lane. The outer diameter is $D_{0}=72 \mathrm{~m}$, and the inner diameter is $D_{i}=63.5 \mathrm{~m}$ [6]. The width of the traffic lane on a single-lane approach is $5 \mathrm{~m}$, and on a two-lane approach it is $7.5 \mathrm{~m}$. Beside the road traffic, there is conflicting tram traffic with a track width of $2.2 \mathrm{~m}$ (Figure 1). Fitting the tram in the roundabout reduces security and increases time losses.

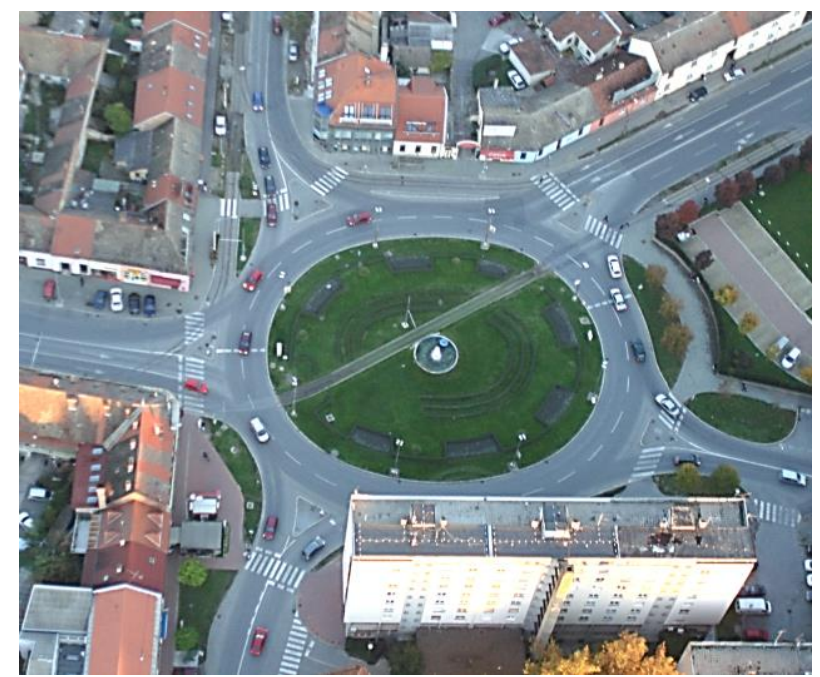

Figure 1 Aerial view of the Đakovština roundabout

Pedestrian crossings are kept out of the roundabout, and they are well lit and marked with horizontal and vertical signals. The central island is landscaped with grass, hedges, and a fountain, decorating it and identifying the intersection without reducing its internal visibility.

The Đakovština roundabout represents a link between urban and suburban transport, which leads to a complex picture of traffic in the morning and afternoon peak loads. 


\section{PROPOSED TURBO ROUNDABOUT}

Due to the proximity of the surrounding buildings and the placement of the existing infrastructure, the pavement of the current roundabout cannot be extended to make more entrance and exit traffic lanes on specific legs, which makes it impossible to build a traditional turbo roundabout (two lanes per each leg). Instead, in this work we propose a turbo roundabout that takes advantage of the current situation and environment, keeping its design realistic with minimal changes in approaches.

The current roundabout has a varying number of incoming lanes, which further complicates the design of a turbo roundabout. We selected an ovular turbo roundabout [1], keeping the number of lanes on the access road unchanged because the pavement cannot be expanded. A special feature of this roundabout is the tram flow through the central island, which requires more space and increases the number of conflicts in the intersection. In the design process, there were some problems with placing the translational axes because the access roads are not perpendicular to each other. The width of the entry and exit lanes are kept unchanged, and the selected design radii are $19.95 \mathrm{~m}, 29.95 \mathrm{~m}$, and $24.90 \mathrm{~m}$ (Table 1). The inner lane is $4.95 \mathrm{~m}$ wide, the outer lane is $4.75 \mathrm{~m}$, and width of the truck apron of the central island is $2.5 \mathrm{~m}$.

\subsubsection{Preliminary design of the turbo roundabout}

We designed the turbo roundabout by using TORUS 5 Roundabouts software, an addition to AutoCAD that contains a variety of design approaches and allows for adjustments to various design parameters. To begin designing a solution, we assessed the guidelines for designing turbo roundabouts [1, 4, 7, 8]. In the design guidelines [1], the recommended dimensions of the turbo roundabout depend on its size. The existing Đakovština roundabout is a large two-lane roundabout, and an adequate replacement is a large turbo roundabout, which we selected with the parameters shown in Table 1.

Table 1 Selected geometrical parameters of the turbo roundabout

\begin{tabular}{|l|l|}
\hline Inner edge radius of the central island transit part & $R_{0}=17.45 \mathrm{~m}$ \\
\hline Inner edge radius of roadway (inner lane) & $R_{1}=19.95 \mathrm{~m}$ \\
\hline Outer edge radius of roadway (inner lane), including 30-cm-wide edge of dividing island (delineator) & $R_{2}=24.90 \mathrm{~m}$ \\
\hline Inner edge radius of roadway (outer lane), including 30-cm-wide of division island & $R_{3}=25.20 \mathrm{~m}$ \\
\hline Outer edge radius of roadway (outer line) & $R_{4}=29.95 \mathrm{~m}$ \\
\hline $\begin{array}{l}\text { Inner edge marginal strip radius (on the driving side) width of } 0.15 \mathrm{~m} \text { (total marginal lane width of } 0.45 \\
\text { m) }\end{array}$ & $r_{1}=20.45 \mathrm{~m}$ \\
\hline $\begin{array}{l}\text { Inner edge marginal strip radius (on the driving side) of } 10 \mathrm{~cm} \text { width, including 30-cm-wide dividing } \\
\text { island (total marginal lane width of } 20 \mathrm{~cm} \text { ) }\end{array}$ & $r_{2}=24.70 \mathrm{~m}$ \\
\hline Inner edge of roadway (outer lane), including 30-cm-wide edge of dividing island & $r_{3}=25.40 \mathrm{~m}$ \\
\hline $\begin{array}{l}\text { Inner edge marginal strip radius (on the driving side) width of } 15 \mathrm{~cm} \text { (total marginal lane width of } 45 \\
\text { cm) }\end{array}$ & $r_{4}=29.45 \mathrm{~m}$ \\
\hline Asphalt surface width of the inner circulatory lane & $B_{\mathrm{u}}=4.95 \mathrm{~m}$ \\
\hline Asphalt surface width of the outer circulatory lane & $B_{\mathrm{v}}=4.75 \mathrm{~m}$ \\
\hline Width between outer marginal strips & $b_{\mathrm{v}}=4.05 \mathrm{~m}$ \\
\hline Width between inner marginal strips & $b_{\mathrm{u}}=4.20 \mathrm{~m}$ \\
\hline Distance between outer points of translational axis & $D_{0}=5.15 \mathrm{~m}$ \\
\hline Distance between inner points of translational axis & $D_{\mathrm{i}}=4.75 \mathrm{~m}$ \\
\hline
\end{tabular}

The geometry of a roundabout depends much on the design vehicle selected. Because this roundabout serves mostly urban traffic, with few heavy freight vehicles (Table 2), we selected a public transport vehicle (bus) as the design vehicle with a wheel base of $6.60 \mathrm{~m}$ and a total length of $12.50 \mathrm{~m}$, corresponding quite well to Osijek's public transport vehicles [9].

The movements of the design vehicles should be checked to confirm the selected entering and exit radii through the design intersection. These movements were checked by using the "evaluate movements" function in TORUS 5.0, which produced trajectories and movement widths for all entrances and exits (Figure 2). 


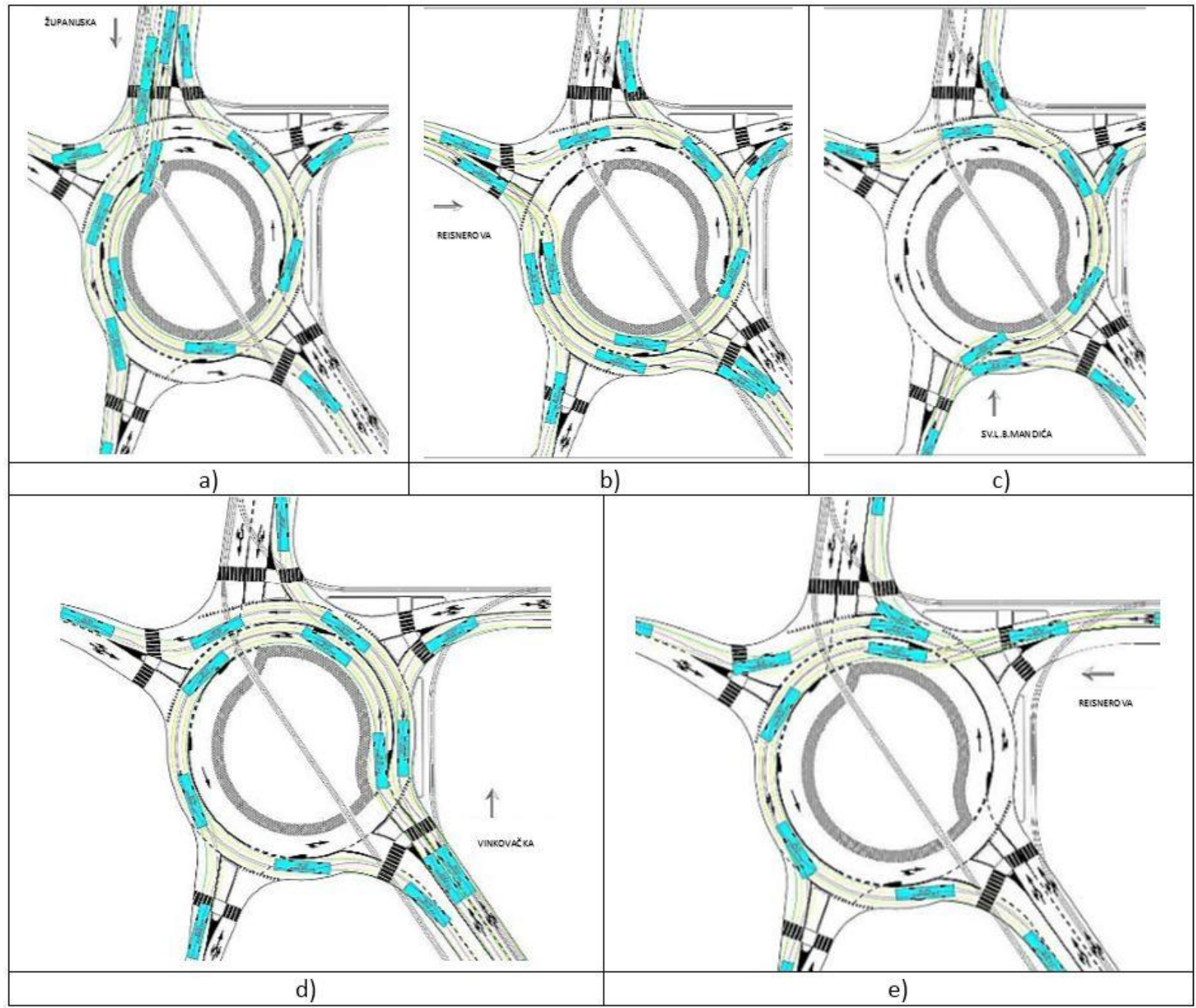

Figure 2 Movement of design vehicles at the entrances [10]

On the designed turbo roundabout, cyclists and pedestrians use the same cyclist and pedestrian crossings as on the existing roundabout. To ensure the vehicles can stop smoothly for passing pedestrians without disturbing the main traffic flow, the passings are so they have a minimum distance of $5 \mathrm{~m}$ from the edge of the circular lane, according to the design rules.

The central island in the turbo roundabout is a set with an offset axis, which is characteristic of these intersections. This is done because the entrances to the main axis can form an additional lane. We selected a spiral end for the central island in order to channel traffic and better visually integrate the island into its environment. The truck apron of the central island can be used by larger vehicles if necessary (Figure 3 ). 


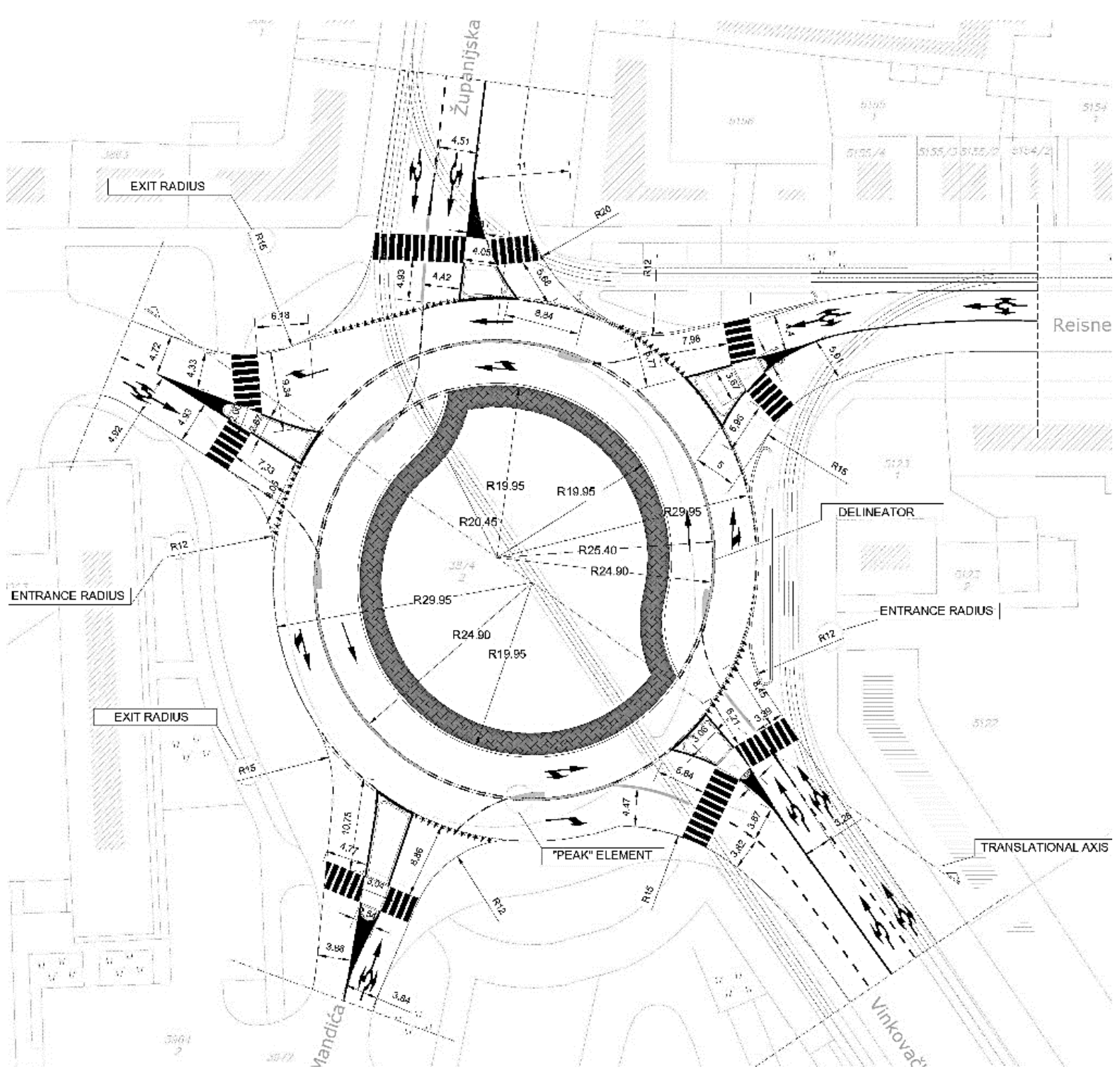

Figure 3 Conceptual design of the turbo roundabout [10]

Timely, quality traffic signaling is very important in the turbo roundabout, because there is no realignment in the intersection, and drivers must know the direction of their destination in order to choose the appropriate lane. Horizontal and vertical traffic signs must be placed in accordance with the regulations on traffic signs, signaling, and equipment on roads $[1,8]$. Figure 4 shows the designed turbo roundabout in the existing environment. 


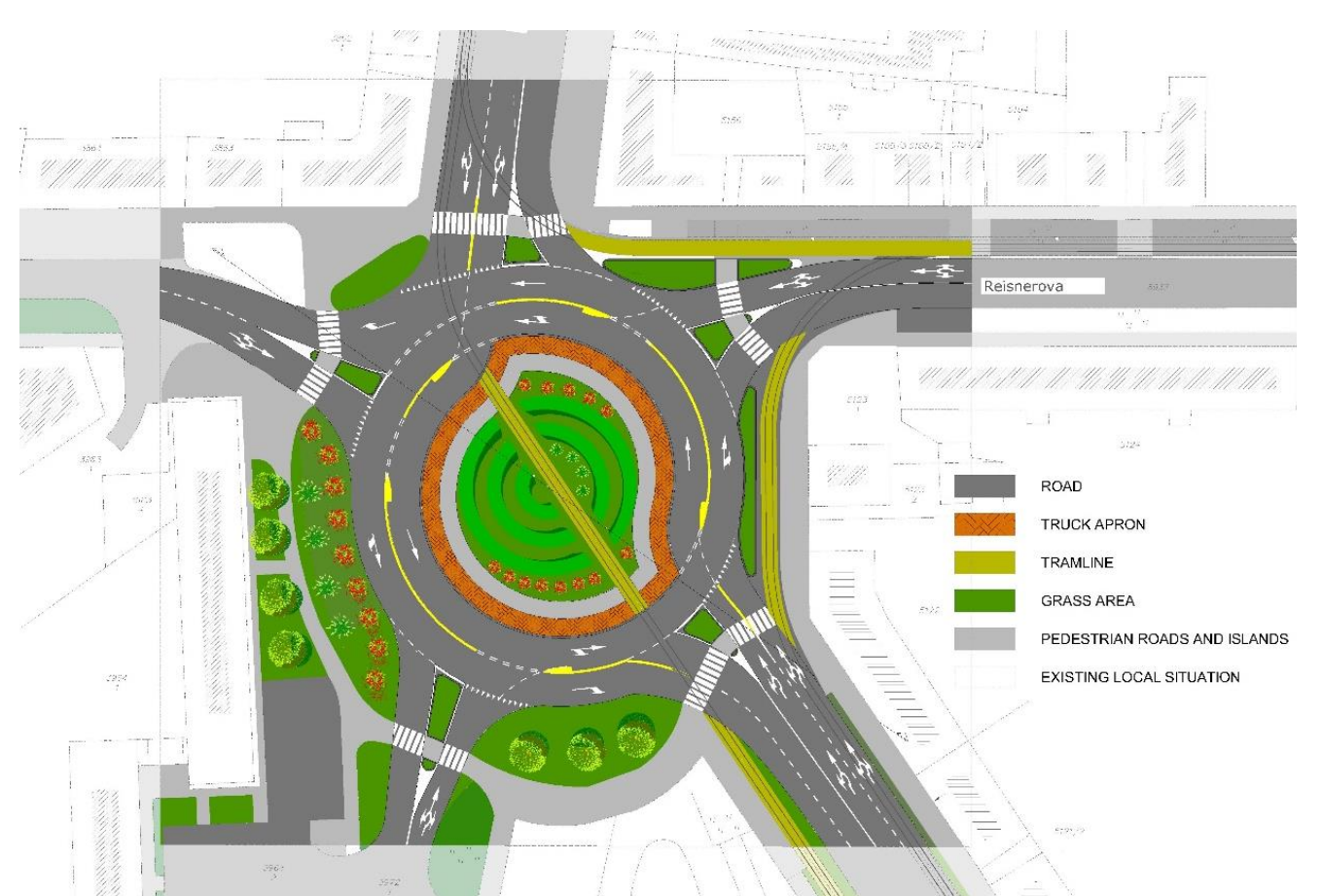

Figure 4 Fitting the designed turbo roundabout into the existing environment [10]

\section{TRAFFIC SIMULATION}

Many traffic models have been developed that are suitable for different traffic analyses and have different spatial and time parameters. Microsimulation models are designed to analyze in real-time for short-term and medium-term planning. To compare solutions, we used the PTV VISSIM microsimulation model. The VISSIM traffic model uses the Wiedemann psycho-physical car-following model as a sub-model that models the longitudinal motion of vehicles. Driver behavior is modeled with four driving regimes: free driving, approaching a car queue, driving in a queue, and braking. The basic mathematical models in VISSIM are the gap acceptance model, the car following model, and the lane change model [11].

\subsection{Determining traffic load for the traffic simulation}

The traffic load of the existing Đakovština roundabout was determined by counting vehicles in a video recording, and the data was collected to find the critical traffic load. This traffic load data was collected on May 27, 2015 during the afternoon peak hour from 15:00 to 16:00. Table 2 shows the counted traffic volume and distribution; the traffic flow includes cyclists who used the circular lane for passing through the intersection. The traffic volume was reduced to an equivalent load (EJA: equivalent personal car units) by applying the relevant factors, which allows for comparison of alternative solutions [12].

Table 2 Traffic volume and distribution of vehicles

\begin{tabular}{|c|c|c|c|c|c|c|c|c|c|}
\hline & & PA & $\mathrm{HV}$ & HFV & BUS & MOT & $\mathrm{BIC}$ & EJA & PJ \\
\hline \multirow{2}{*}{ REISNEROVA } & ENTRANCE & 506 & 0 & 0 & 6 & 4 & 0 & 517 & \multirow{2}{*}{118} \\
\hline & EXIT & 356 & 3 & 0 & 2 & 4 & 4 & 366 & \\
\hline \multirow{2}{*}{ ŽUPANIJSKA } & ENTRANCE & 668 & 0 & 0 & 4 & 12 & 4 & 682 & \multirow{2}{*}{70} \\
\hline & EXIT & 314 & 2 & 0 & 10 & 6 & 6 & 335 & \\
\hline \multirow{2}{*}{ REISNEROVA } & ENTRANCE & 370 & 2 & 0 & 0 & 8 & 8 & 381 & \multirow{2}{*}{127} \\
\hline & EXIT & 608 & 4 & 0 & 0 & 10 & 4 & 621 & \\
\hline \multirow{2}{*}{ SV.L.B.MANDIĆA } & ENTRANCE & 508 & 8 & 0 & 18 & 2 & 0 & 548 & \multirow{2}{*}{105} \\
\hline & EXIT & 660 & 6 & 0 & 8 & 12 & 2 & 688 & \\
\hline \multirow{2}{*}{ VINKOVAČKA } & ENTRANCE & 708 & 6 & 0 & 4 & 6 & 8 & 730 & \multirow{2}{*}{122} \\
\hline & EXIT & 822 & 2 & 0 & 12 & 6 & 4 & 848 & \\
\hline \multirow{2}{*}{ SUMA } & ENTRANCE & 2760 & 16 & 0 & 32 & 32 & 20 & 2858 & \multirow{2}{*}{542} \\
\hline & EXIT & 2760 & 17 & 0 & 32 & 38 & 20 & 2858 & \\
\hline
\end{tabular}

PA: passenger car; HV: heavy vehicle; HFV: heavy freight vehicle; MOT: motorcycle; BIC: bicycle 


\subsection{Simulated results of the two-lane roundabout}

Here, the analyzed parameters were the queue length (QLEN), maximum queue length (QLENmax), and average delay (VEHDELALL).

The simulated current two-lane roundabout in VISSIM shows the expected results, with high queue length and delays. As shown in Figure 5, the most critical approach is "Reisnerova 1" from the north, by all parameters. It has an average queue length of $45.89 \mathrm{~m}$, the highest queue length in the simulation of $192.45 \mathrm{~m}$, and the highest average delay-for exiting on Vinkovačka Street—of $67 \mathrm{~s} /$ vehicle.

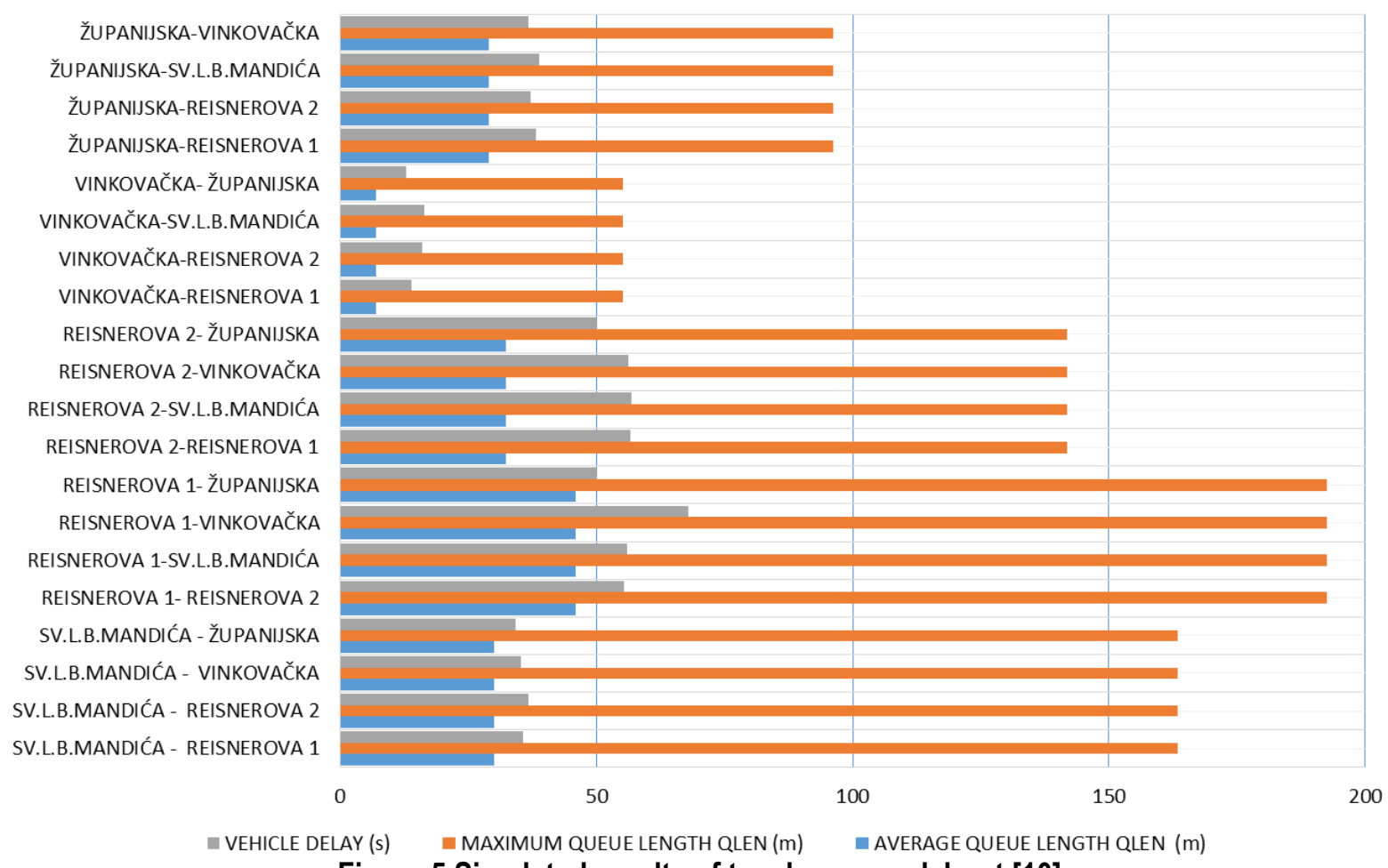

Figure 5 Simulated results of two-lane roundabout [10]

Table 3 shows greater queues at single-lane entrances, as expected.

Table 3 Simulated results of the two-lane roundabout

\begin{tabular}{|c|c|c|c|c|}
\hline \multicolumn{2}{|c|}{ Direction } & Average Queue & Maximum Queue & Average Delay \\
\hline \multirow{4}{*}{ SV.L.B.MANDIĆA } & REISNEROVA 1 & \multirow{4}{*}{30.07} & \multirow{4}{*}{163.36} & 35.72 \\
\hline & REISNEROVA 2 & & & 36.66 \\
\hline & VINKOVAČKA & & & 35.27 \\
\hline & ŽUPANIJSKA & & & 34.21 \\
\hline \multirow{4}{*}{ REISNEROVA 1} & REISNEROVA 2 & \multirow{4}{*}{45.89} & \multirow{4}{*}{192.49} & 55.31 \\
\hline & SV.L.B.MANDIĆA & & & 55.98 \\
\hline & VINKOVAĆKA & & & 67.92 \\
\hline & ŽUPANIJSKA & & & 50.08 \\
\hline \multirow{4}{*}{ REISNEROVA 2} & REISNEROVA 1 & \multirow{4}{*}{32.32} & \multirow{4}{*}{141.74} & 56.66 \\
\hline & SV.L.B.MANDIĆA & & & 56.94 \\
\hline & VINKOVAČKA & & & 56.22 \\
\hline & ŽUPANIJSKA & & & 50.17 \\
\hline \multirow{4}{*}{ VINKOVAČKA } & REISNEROVA 1 & \multirow{4}{*}{6.93} & \multirow{4}{*}{55.07} & 13.98 \\
\hline & REISNEROVA 2 & & & 16.01 \\
\hline & SV.L.B.MANDIĆA & & & 16.54 \\
\hline & ŽUPANIJSKA & & & 12.92 \\
\hline \multirow{4}{*}{ ŽUPANIJSKA } & REISNEROVA 1 & \multirow{4}{*}{29.07} & \multirow{4}{*}{96.27} & 38.21 \\
\hline & REISNEROVA 2 & & & 37.26 \\
\hline & SV.L.B.MANDIĆA & & & 38.89 \\
\hline & VINKOVAČKA & & & 36.72 \\
\hline
\end{tabular}




\subsection{Simulated results of the turbo roundabout}

In the simulation of the turbo roundabout, the most critical flow was Reisnerova Street from the direction of the Zrinjevac sports hall ("Reisnerova 1") with a queue length of $30.64 \mathrm{~m}$, as shown in Figure 6. Reisnerova also has largest average vehicle delay of $51.90 \mathrm{~s}$, while the maximum queue length in the turbo roundabout is on Sv. L. B. Mandića Street. The shortest delays occur on Reisnerova Street from the west and Vinkovačka with queue lengths of $3.86 \mathrm{~m}$ and $6.06 \mathrm{~m}$, respectively (Table 4).

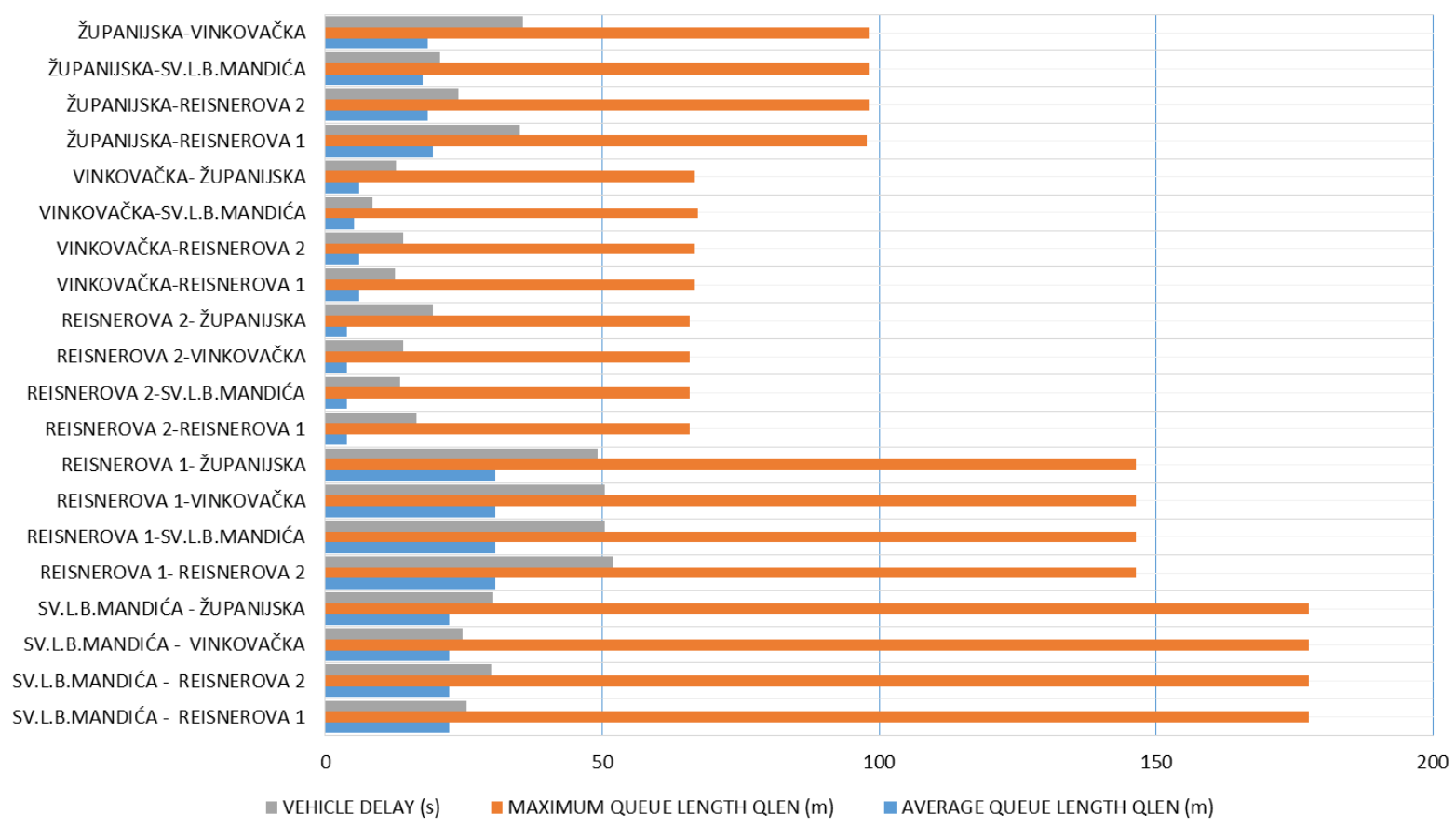

Figure 6 Simulated results of the turbo roundabout [10]

Table 4 Simulated results of the turbo roundabout

\begin{tabular}{|c|c|c|c|c|}
\hline \multicolumn{2}{|c|}{ Direction } & $\begin{array}{l}\text { Average Queue Length } \\
\text { (qlen) [m] }\end{array}$ & $\begin{array}{c}\text { Maximum Queue } \\
\text { Length (QLENmax) [m] }\end{array}$ & $\begin{array}{l}\text { Average Delay (VEHDELALL) } \\
\text { [s] }\end{array}$ \\
\hline \multirow{4}{*}{ SV.L.B.MANDIĆA } & REISNEROVA 1 & \multirow{4}{*}{22.32} & \multirow{4}{*}{177.65} & 25.51 \\
\hline & REISNEROVA 2 & & & 29.90 \\
\hline & VINKOVAČKA & & & 24.69 \\
\hline & ŽUPANIJSKA & & & 30.32 \\
\hline \multirow{4}{*}{ REISNEROVA 1} & REISNEROVA 2 & \multirow{4}{*}{30.64} & \multirow{4}{*}{146.34} & 51.90 \\
\hline & SV.L.B.MANDIĆA & & & 50.53 \\
\hline & VINKOVAČKA & & & 50.42 \\
\hline & ŻUPANIJSKA & & & 49.16 \\
\hline \multirow{4}{*}{ REISNEROVA 2} & REISNEROVA 1 & \multirow{4}{*}{3.86} & \multirow{4}{*}{65.87} & 16.42 \\
\hline & SV.L.B.MANDIĆA & & & 13.43 \\
\hline & VINKOVAĆKA & & & 14.12 \\
\hline & ŻUPANIJSKA & & & 19.38 \\
\hline \multirow{4}{*}{ VINKOVAČKA } & REISNEROVA 1 & \multirow{4}{*}{6.06} & \multirow{4}{*}{66.78} & 12.51 \\
\hline & REISNEROVA 2 & & & 14.06 \\
\hline & SV.L.B.MANDIĆA & & & 8.53 \\
\hline & ŽUPANIJSKA & & & 12.70 \\
\hline \multirow{4}{*}{ ŽUPANIJSKA } & REISNEROVA 1 & \multirow{4}{*}{18.49} & \multirow{4}{*}{98.07} & 35.03 \\
\hline & REISNEROVA 2 & & & 24.07 \\
\hline & SV.L.B.MANDIĆA & & & 20.70 \\
\hline & VINKOVAČKA & & & 35.76 \\
\hline
\end{tabular}




\section{DISCUSSION}

Figure 7 compares the simulated average vehicle delay for the existing two-lane roundabout and the turbo roundabout, and Figure 8 compares the simulated average and maximum queue lengths of vehicles at the roundabout entrance.

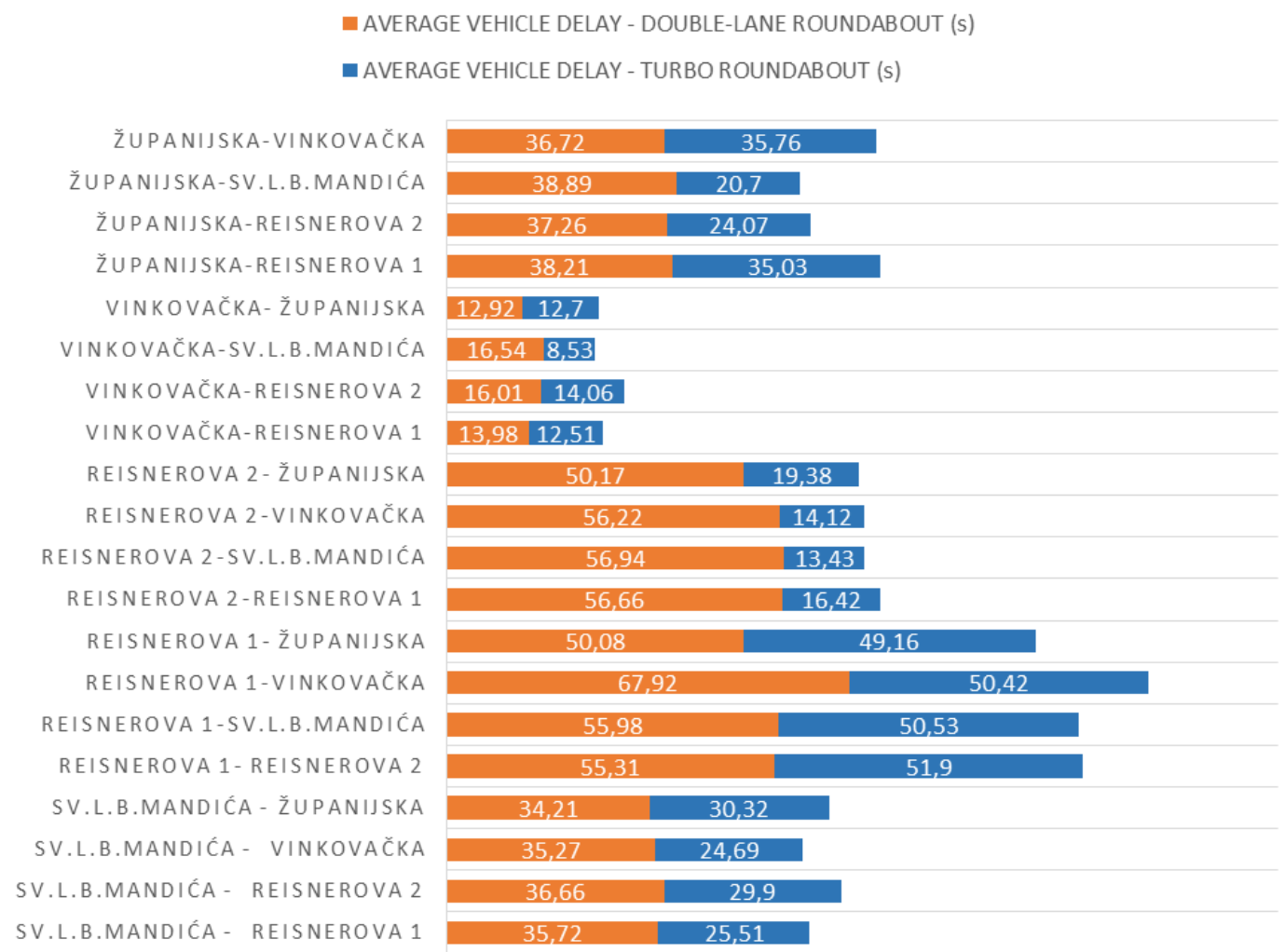

Figure 7 Average vehicle delay: two-lane roundabout versus turbo roundabout [10]

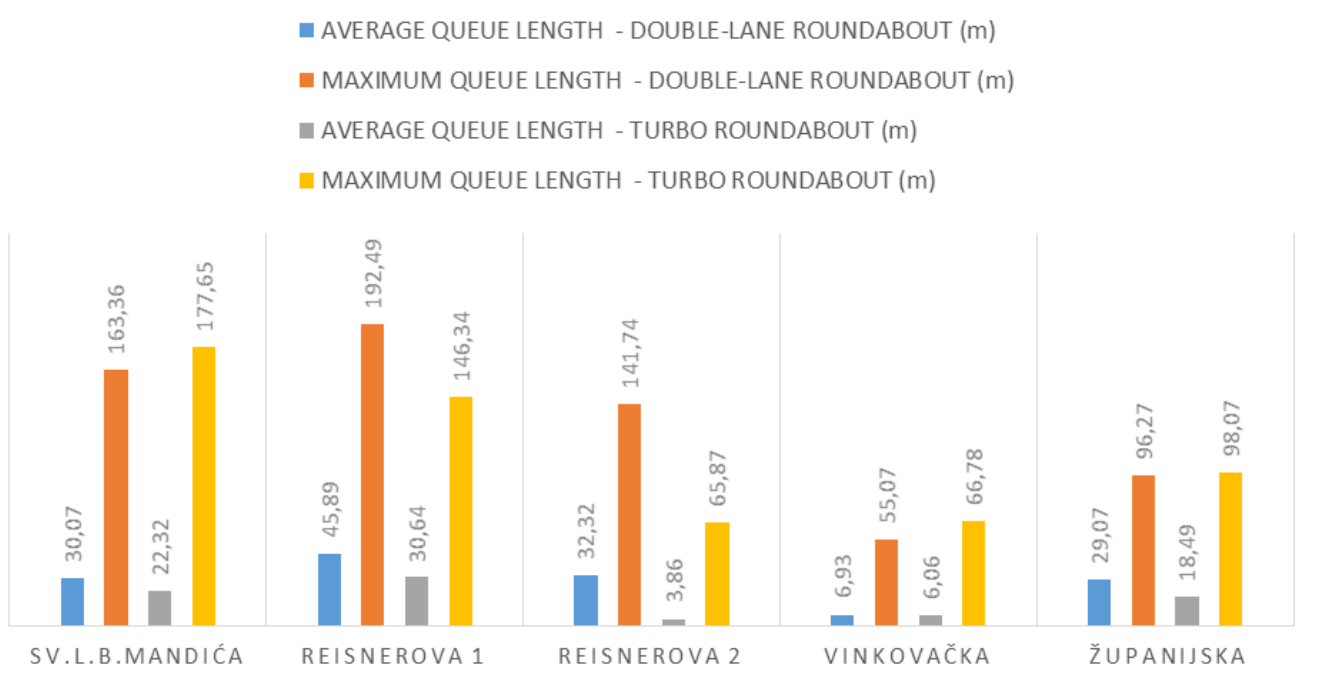

Figure 8 Average and maximum queue length: two-lane roundabout versus turbo roundabout [10]

For all parameters, the minimum difference between the current two-lane roundabout and turbo roundabout was in the direction of Vinkovačka Street, and there are similar results for Županijska Street. The turbo roundabout has significantly better flow of vehicles going west on Reisnerova Street, with an average queue length of about 30 $\mathrm{m}$, maximum queue length less than about $75 \mathrm{~m}$, and average minor delays of about $40 \mathrm{~s}$. This direction also showed the most improvement in functionality in the reconstructed roundabout. 
Looking at Reisnerova Street from the east, the turbo roundabout again shows notable improvements: the average queue length is reduced by about $15 \mathrm{~m}$, and the maximum queue length is reduced by about $40 \mathrm{~m}$. The average delay remains the same, except for Vinkovačka Street in the direction of Reisnerova, showing a decrease of about $17 \mathrm{~s}$. On the roundabout entrance from Sv.L.B.Mandića Street, the turbo roundabout has an average queue length decreased by about $10 \mathrm{~m}$, and for two streams of traffic flow it decreases the average delay by about $10 \mathrm{~s}$ (Figure 7). The only deviation from these functional improvements is that the maximum queue length of the turbo roundabout is about $15 \mathrm{~m}$ longer.

\section{CONCLUSION}

The traffic load at peak hours for the Đakovština two-lane roundabut exceeds its capacity, which greatly delays traffic at this critical point of Osijek's urban transport network. Because of drivers' insecurities when changing lanes in the two-lane roundabout, they favor the outer lane, which increases traffic delays and decreases safety. In this paper, we give the basic steps for designing a replacement turbo roundabout and compare this simulated roundabout to the current roundabout, using the VISSIM microsimulation traffic model.

The turbo roundabout showed better functional characteristics. However, at peak traffic load, these improvements were less dramatic than expected, except at the west entrance of Reisnerova Street, where the results were significantly better. The analysis included functional indicators such as the average vehicle delay and the average and maximum vehicle queue lengths at the intersection entrance. For a more detailed analysis, it is necessary to analyze the indicators of traffic safety, which according to experiences in the world show improvement in the turbo roundabout. Our results should be viewed in the context that our model was based on input data from one traffic count at the peak hour, and producing a more realistic set of input traffic data will require monitoring for a longer time period. Also, our results were produced by uncalibrated traffic models, but in this basic evaluation of alternative solutions, this fact does not significantly affect our final assessment.

\section{References}

[1] Smjernice za projektiranje kružnih raskrižja na državnim cestama, Građevinski fakultet Sveučilišta u Rijeci, 2014, Rijeka.

[2] Tollazzi, T. 2007: Kružna raskrižja, IQ Plus d.o.o., Kastav, Rijeka.

[3] Tollazzi, T. 2015: Alternative Types of Roundabouts An Informational Guide, Springer International Publishing Switzerland.

[4] Cambpbell, D.; Jurisich, I.; Dunn, R. 2012: Improved multi - lane roundabout designs for urban areas, NZ Transport Agency research report 476.

[5] Ištoka Otković, I.; Zagvozda, M. 2015: Aspects of Traffic Safety of Two-lane Roundabout, in: AnkaMašekTonković (Ed), 4th International Scientific Symposium: Economy of Eastern Croatia - Vision and Growth, University of Osijek, Faculty of Economics in Osijek, Osijek, pp. 780-788.

[6] Omazić, I.; Dimter, S.; Barišić, I. 2010: Kružna raskrižja - suvremeni način rješavanja prometa u gradovima. egfos., 1, pp. 54-66. http://dx.doi.org/10.13167/2010.1.6

[7] Kenjić, Z. 2009: Kružne raskrsnice rotori, Priručnik za planiranje i projektovanje kružnih raskrsnica - rotora, IPSA Institut Sarajevo, Sarajevo.

[8] Silva, A. B.; Santos, S.; Gaspar, M. 2013: Turbo-roundabout use and design, CITTA 6th Annual Conference on Planning Research, Responsive Transports for Smart Mobility, Coimbra, Portugal.

[9] http://www.gpp-osijek.com/files/download/Bus.pdf. Accessed 3 September 2015.

[10] Kolak, I. 2015: Usporedba varijantnih rješenja rekonstrukcije raskrižja primjenom mikorsimulacijskog prometnog modela, diplomski rad, Građevinski fakultet Sveučilišta J.J. Strossmayera u Osijeku, Osijek.

[11] Šraml, M.; Jovanović, G. 2014: Mikrosimulacije u prometu (radni udžbenik s primjenom VISSIM-a), Univerza v Mariboru, Maribor.

[12] Dadić, I; Kos, G. 2007: Teorija i organizacija prometnih tokova, Sveučilište u Zagrebu, Fakultet prometnih znanosti, Zagreb, Available online: http://www.ipv-zg.hr/docs/studenti/Skripta_TIOPT.pdf. Accessed 23 October 2015. 